\title{
FROM ANTHROPOCENTRISM TO SUSTAINCENTRISM: CASE STUDY ON BEVERAGE COMPANIES IN INDIA
}

\author{
Yasmeen Shamsi Rizvi*, Raksha Garg* \\ * Jamia Millia Islamia, New Delhi, India \\ corresponding author: Raksha Garg, e-mail: rakshagarg15@gmail.com
}

This work is licensed under a

Creative Commons Attribution 4.0

International License

\author{
Review paper \\ Received: May $12^{\text {th }}, 2020$ \\ Accepted: July $17^{\text {th }}, 2020$ \\ HAE-1961 \\ https://doi.org/10.33765/thate.11.3.3
}

\begin{abstract}
Business organizations have been facing an unprecedented level of criticisms for being one of the prime contributors to the deterioration of environmental health. These criticisms have prompted organizations to make environmental sustainability a part of their business strategy. The case study on the beverage companies show how organizations are making a shift from anthropocentrism to sustaincentrism. Here we have mainly focussed on how PepsiCo and Coca-Cola have transformed their image from the one that contributes to bad health of the environment to the one that operates in an environment-friendly manner and how their environmental strategies have helped them in balancing the needs of stakeholders while earning profits.
\end{abstract}

Keywords: environment, anthropocentrism, sustaincentrism, ecocentrism, strategy, sustainability

\section{INTRODUCTION}

"The blind pursuit of profit at all costs is untenable. It is essential that we make money the right way. After all, if communities suffer as a result of a company's actions, those returns are not sustainable." - Indra Nooyi, Chairman, and CEO of PepsiCo.

Organizations have been facing increasing criticisms for mercilessly exploiting the environment and society to satisfy their greed for huge profits. Today, companies cannot argue that environmental degradation is an unintended consequence of their corporate structure that relies on profits to ensure survival, thus resulting in environmental issues which are not intended in the first place. Given the seriousness associated with environmental health, such as rapid depletion of the ozone layer, global warming, etc., many organizations, if not all, have started integrating sustainability into their business strategy and earned huge profits in the process. These profits can be associated with the fact that today is the time of green consumerism, when people want to buy products that have been produced without causing any negative impact on the environment. Consumers are ready to pay even premium price that goes into the production of such products. The corporate structure is based on "Survival of the fittest" [1] which leads to unethical practices in the wake of making unlimited profits [2]. In this 
study we argue that today the definition of survival of the fittest has changed and it calls for adopting a sustaincentric approach since going green means gaining competitive advantage in the industry [3].

The following case study is a classic example of how companies can operate truly sustainably in spite of being in an industry where water consumption, energy consumption, use of plastic or such other resources are unavoidable. There was a time when these companies faced a lot of criticisms for causing water scarcity, dumping plastic, particularly in India, and for excessive energy consumption. This was due to the fact that like other companies, PepsiCo and Coca-Cola also followed the traditional approach, wherein the basic assumption was that the natural resources could be totally replaced by technological advancements (like there would be an invention of alternative sources of energy, water, etc.) and that the only responsibility that the organization had was towards their shareholders. With this approach in mind, organizations would exploit resources without thinking about the consequences this would have on the environment. It was in the late $20^{\text {th }}$ century, that the stakeholder theory gained momentum and organizations began realizing its responsibility towards various stakeholders - community and environment being its major part [4].

\section{THEORETICAL CONSTRUCTS WOVEN INTO THIS CASE STUDY ANTHROPOCENTRISM ECOCENTRISM - SUSTAINCENTRISM}

Anthropocentrism, broadly stated is "a perspective that human beings are the most significant species on the planet, and nature is valuable only insofar as it is valuable to human beings" [5]. This perspective has contributed to several environmental problems. For example, if people would cut down trees indefinitely to build houses or for another purpose without considering the environmental impact of their actions, it would cause problems associated with climate change, loss of biodiversity, etc. This is why this theory has been widely criticised by the advocates of ecocentrism. The ecocentric approach recognises and respects the intrinsic value of all living things on earth, regardless of their usefulness to humans [6].

Both anthropocentrism and ecocentrism represents polar ends of a spectrum, where the former concept gives utmost importance to human beings at the cost of the environment and the latter places nature above everything else and ignores the fact that man has a unique quality (for example the ability to think rationally and make freewill decisions) that differentiates them from other living things [7]. It is unrealistic to expect organizations to follow ecocentrism because of their excessive reliance on natural resources [8], therefore, in order to balance the two perspectives, organizations should try to find solutions to environmental problems, for example, by finding alternative sources of energy. They should avoid using precious resources unless something is a necessity as opposed to desire [9].

Sustainable business practices require organizations to change their anthropocentric approach and make a shift in their culture [10]. Sustaincentrism had emerged as a new theory (in the year 1995), that balances the previous two extreme approaches. "A sustaincentric orientation is defined as an ongoing process of equitably including a highly interconnected set of seemingly incompatible social, ecological and economic systems through collaborate theorization of coordinated approaches that harness the collective cognitive and operational capabilities of multiple local and global social, ecological, economic stakeholders operating as a unified network or system" [11]. In terms of environmental sustainability, human or organizational behaviour is guided by constraints imposed by the ecological environment.

PepsiCo and Coca-Cola have seen those days when following an anthropocentric approach; they had faced a massive amount of criticisms for causing harm to the environment for the sake of making money. In such a situation a 
company might make profits initially, but when the stakeholders, like the local community, the environmental activist, or the consumers become aware of the environmental or social harm caused by the organizations operations, they start questioning the company's way of operations, they also take extreme measures like shunning the use of the company's products that would ultimately have an impact on company's profits. Another reason why companies rethink their anthropocentric methods is because of the realization that if they want to sustain in the long run, they have to protect the environment because they can only sustain till there are resources available to serve their purpose.

This case study has focussed on the ecological part of sustaincentrism given the seriousness and urgency associated with environmental problems.

\section{WHY SUSTAINCENTRISM: CRITICISMS ENCOUNTERED BY THE COMPANIES USING ANTHROPOCENTRIC APPROACH}

PepsiCo and Coca-Cola had set up factories in post-liberalization India to take advantage of the extremely cheap supply of water and fewer safety regulations. This in itself was a wrong start because eventually with this approach, these companies started earning huge profits without actually being answerable to the environmental problems. Following the anthropocentric approach, while people in India were suffering as a result of environmental problems, these companies were making two billion in profit each year. The Coca-Cola Company alone was extracting 500,000 to 1.5 million litres of groundwater daily [12]. PepsiCo and Coca-Cola were doing well by following the anthropocentric approach. They were earning huge returns until they were bombarded with criticisms for causing environmental problems in the country that intensified in the late 90s. Due to the criticisms, the companies started losing its market share in India. For example, 3 states namely Gujarat, Madhya Pradesh and
Rajasthan had stopped selling their cola products in government offices and educational institutions [13]. The main criticisms that prompted these companies to make a shift towards sustaincentrism are as follows:

\section{Water shortage}

Starting from the 2000s, PepsiCo was accused of using groundwater for its bottling operations in India leading to water shortage due to its ever-increasing population. A prominent social activist said that "this water war is leading to acute water shortages and is denying the local communities their fundamental right to water". The high court of Kerala ruled out in favour of the local community of Kerala and said that "water belongs to people and not to Coke and Pepsi" [14]. Coca-Cola operates 58 water-intensive bottling plants in India. Given this number, it is natural to expect the company to ensure sustainable usage of water. Yet, Coca-Cola topped the list for the wrong reasons, whenever there have been discussions on the water scarcity in India. In 2004, several farmers participated in a 10 days march in Uttar Pradesh, an agriculture-dependent state, against the groundwater depleting caused by the company's operations. "Drinking Coke is like drinking farmer's blood in India", said the protest organizer Nandlal Master. Due to these allegations, the sale of Coca-Cola products dropped 30 to $40 \%$ [15].

\section{Packaging related pollution}

The problem associated with packaging is that both Coca-Cola and PepsiCo used tonnes of plastic for packaging without adequate measures taken for recycling or reusing. The problem for a developing nation like India was twofold. Firstly, these companies had been accused of exporting plastic waste to India, much of which was not recycled. Secondly, they were setting up plastic production plants in India which would pose a serious threat to environmental health, since a huge amount of waste is generated in the plastic production 
process. Satish Vangal, an environmentalist from Madras said that "We have enough problems dealing with our own plastic wastes; why should we import other peoples' rubbish?" [16].

\section{Agricultural problems}

Central Pollution Control Board in 2003 also found that the sludge from Coca-Cola's Uttar Pradesh factory was contaminated with high levels of cadmium, lead, and chromium. These companies were also offloading their sludge by distributing it as free fertilizers to farmers thus causing land pollution [15]. "The farmers were encouraged to spread the sludge on their land; the corporation said it was an excellent fertilizer that would improve their yields. This provided a cheap and convenient waste disposal mechanism for the factory" [17].

Both these companies have been responsible for causing water shortage, thus adding to the plight of farmers in India. Despite these criticisms, these companies have experienced an $11 \%$ compound annual growth from 2015 to 2017 [18]. This would not have been possible if these companies had not changed their anthropocentric approach.

\section{WHAT HAVE THE COMPANIES DONE TO ACHIEVE SUSTAINCENTRISM?}

These companies received a significant amount of recognition in the past few years due to the various sustainability initiatives they have taken in response to the criticisms they have been facing as mentioned above. PepsiCo made a huge leap from anthropocentrism to sustaincentrism when Indra Nooyi was appointed as the CEO in 2006 (now Ex-CEO). She introduced the vision named "performance with purpose" which is a fundamental belief that their long-term success is linked to the sustainability of the entire world [19]. The vision includes the promise made to its shareholders for increased profits and the promise made to its other stakeholders for greater contribution to the environment and to the society [20]. With this vision, the company has been able to achieve its social and environmental sustainability goals. Using sustaincentric approach, like reducing the consumption of electricity or switching to alternative source of energy, the food and beverage giant was able to achieve an $18 \%$ improvement in its energy efficiency for the past ten years. [21]. Nooyi has always voiced her concern towards sustainability and in one of her recent interviews held at Yale School of Management she said: "I strongly believe that corporations operate with a license from society. It is not appropriate to think about your profit and loss account as (Revenue) (Cost). It really is (Revenue) - (Cost) - (Cost to Society) and that is your real profit" (PepsiCo).

There are some important currently ongoing programs with purpose vision started by PepsiCo. Sustainable farming initiative (SFI) (launched in 2013) is a program aimed at engaging growers around the world to make continual improvement in sustainable agricultural practices, respect human rights, address risk and enhance growers' capabilities. By 2017, 24000 Indian farmers were covered under this program and the company plans to double this number in five years [22]. By reducing water usage - as a part of their initiative - they aimed to achieve a positive water balance in India by 2009 i.e., to return the same amount of water to the local communities they are using for their manufacturing process. During this time the company was also creating check dams to manage water supplies in the local communities [23]. Sustainable plastic management is in accordance with PepsiCo's sustainable packaging policy. In PepsiCo's words: "In addition to understanding its necessary role in protecting the quality and experience consumers have with our products, we respect our responsibility to contribute to the quality of life in our communities by optimizing the use of materials and continually improving our processes" [24].

Ramon Raguarta, current CEO of the company, has also continued with the 
sustaincentric approach. He introduced the new vision of "winning with purpose" which is in line with the "performance with purpose" vision [25]. In 2019, PepsiCo has partnered with Nepra, a waste management firm, to manage plastic waste in West Bengal [26].

Coca-Cola, too, has been proactive in this race towards achieving sustaincentrism as its core strategy. The company's mantra is "we strive to leave things better than we first inherited". The company took a wide range of initiatives [27]. Inspired by the Indian government's vision to source $40 \%$ of the cumulative electric power capacity from non-fossil based energy sources by 2030 , the company has set a goal to achieve a $50 \%$ green energy target by 2020. To achieve this, they are adopting briquettes that are made out of agricultural waste, like coconut shells and groundnuts, increasing the use of solar power, innovating technologies that consume less energy, like a switch to LED bulbs, etc. [28]. The company uses agricultural waste to meet the requirements for a quarter of its energy needs [29]. As a part of their plastic waste management initiatives, they have minimised the usage of plastic to a great extent. Since 30 $\%$ of the beverage sales comes from returnable glass bottles, the company has also resorted to plant bottle packaging (converting natural sugars found in plants into ingredients used for making Polyethylene Terephthalate (PET) bottles) which is $100 \%$ recyclable, and have increased the use of aluminium cans and tetra packs. Coca-Cola also partnered with United Nations Development Programme (UNDP) to create a circular economy of plastics wherein plastic recycling would connect the point of waste generation to the recyclers, thus leading to zero waste. The company, in partnership with the NGOs and local authorities, have taken more than 300 water replenishment projects to date [28].

As part of their water management activity, Coca-Cola started Anandana, Coca-Cola India foundation which is a company dedicated exclusively to sustainable development and inclusive growth by focussing on water, environment and health of the people of communities [30]. The foundation has helped the company create huge water storage capacities and they have revived the surface water bodies on water scare areas. In 2018, Coca-Cola launched the vision of "World Without Waste", which is a commitment to recycle every bottle that Coca-Cola sells globally [27].

Both companies have also taken measure to make sustainability a part of their core strategy. They have human resource department especially dedicated to handle sustainability issues [28]. These companies have also been very vocal in discussing about their sustainability progress as can be seen from the fact that they religiously publish sustainability report every year. Publishing these reports shows their increased commitment to sustainability. Earlier under anthropocentric approach, organizations didn't care about revealing much to the stakeholders and were only concerned about making money without being answerable for the negative environmental or social impact of their actions [31].

\section{CAN WE SEE TANGIBLE RESULTS? THE THREE PILLARS OF SUSTAINABLE GROWTH WITH PURPOSE VISION}

PepsiCo, Inc was awarded the Global Agriculture Leadership Award and Water Management Excellence Awards, etc. in 2018. Similarly, Coca-Cola was awarded the best company for corporate social responsibility by the economic times and Odisha state energy conservation award in 2015. [28]. Both PepsiCo and Coca-Cola were named among Corporate Responsibility magazine's World's 100 Best Corporate Citizens in 2018 [32]. PepsiCo and Coca-Cola's sustainability journey is an epitome of how companies can earn profits without causing any negative impact on the environment. The companies vision have helped them in achieving positive environmental outcomes and at the same time they have continued to make huge profits and shareholder returns, which have witnessed a growth pattern over the years. This may be due 
to the fact that these companies managed to have huge cost savings as a result of their green initiatives. PepsiCo and Coca-Cola's progress to date in this regard has been summarized below:

PepsiCo - In 2009, PepsiCo India became the first business ever to achieve "Positive Water Balance" in the beverage world. In 2017, the company reduced its greenhouse gas emissions by almost 2.1 million metric tonnes. Various environmental sustainability programs, which include energy, packaging, and waste reduction initiatives, have delivered more than 600 million $\$$ in cost savings over the past five years (2011 - 2016). In 2019, the company achieved a $100 \%$ PET recycling target in the states of Delhi and Maharashtra [25]. The United States named PepsiCo India for the 2019 Secretary of State's Award for Corporate Excellence, recognising its efforts to save more than 17 billion litres of water through community water programs and positively impacting 60,000 community members [33].

Coca-Cola - The company has mostly witnessed double-digit growth in India since 2007, mostly because it has been working towards becoming a more responsible, caring and environmentally friendly company [29]. In India, Coca-Cola has been able to cut down litigation costs that it faced due to unsustainable activities or costs due to shut down under the anthropocentric approach. The company has also been able to save millions due to its green innovative efforts [27]. Due to their packaging improvement efforts, CocaCola has been able to bring savings of more than 3.8 billion worldwide [34]. These savings can be attributed to their green innovative efforts and improved goodwill that in turn enhanced sales. In 2019, 14 of the 18 factories of Hindustan Coca-Cola Beverages have achieved a $100 \%$ LED lighting, which not only helped reducing carbon footprint, but is also expected to reduce the company's energyrelated expenses by RS two and a half million per annum [35]. As a result of their water management activities by 2019, the company has been able to create $100 \%$ water replenishment potential [28]. Table 1 shows the summary of the characteristics of the companies under anthropocentrism and sustaincentrism.

Table 1. Characteristics of companies under anthropocentrism and sustaincentrism

\begin{tabular}{|c|c|c|}
\hline & Anthropocentrism & Sustaincentrism \\
\hline Focus & $\begin{array}{l}\text { Earning profits even } \\
\text { at the cost of social } \\
\text { or environmental } \\
\text { degradation. }\end{array}$ & $\begin{array}{l}\text { Considers human kind } \\
\text { to be the part of the } \\
\text { nature making } \\
\text { humans responsible } \\
\text { towards environment. } \\
\text { Balancing profit } \\
\text { motive with social } \\
\text { and environmental } \\
\text { health. }\end{array}$ \\
\hline $\begin{array}{l}\text { Resource } \\
\text { handling }\end{array}$ & $\begin{array}{l}\text { Overuse of } \\
\text { groundwater } \\
\text { causing water } \\
\text { shortage in the area } \\
\text { of its operation. } \\
\text { Using tonnes of } \\
\text { plastic without } \\
\text { reuse or recycling } \\
\text { measures. No effort } \\
\text { to reduce plastic } \\
\text { usage. }\end{array}$ & $\begin{array}{l}\text { Sustainable use of } \\
\text { water, returning equal } \\
\text { or more water than } \\
\text { used. } \\
\text { Recycling and reusing } \\
\text { plastic. Finding } \\
\text { alternative packaging } \\
\text { materials to reduce } \\
\text { plastic consumption. }\end{array}$ \\
\hline $\begin{array}{l}\text { Practices/ } \\
\text { Strategies }\end{array}$ & $\begin{array}{l}\text { Not answerable for } \\
\text { their negative } \\
\text { environmental or } \\
\text { social impact. } \\
\text { Human resource } \\
\text { department's } \\
\text { primary focus is on } \\
\text { improving } \\
\text { employee's } \\
\text { performance. }\end{array}$ & $\begin{array}{lr}\begin{array}{l}\text { Sustainability } \\
\text { are } \\
\text { published. }\end{array} & \begin{array}{r}\text { reports } \\
\text { regularly }\end{array} \\
\text { Human } & \text { resource } \\
\text { department } & \text { is } \\
\text { concerned } & \text { with } \\
\text { employees } & \text { green } \\
\text { performance. } & \end{array}$ \\
\hline Outcome & $\begin{array}{l}\text { Ban of products in } \\
\text { various cities or } \\
\text { countries due to } \\
\text { unsustainable } \\
\text { methods leading to } \\
\text { loss in market share. } \\
\text { Increased } \\
\text { environmental cost, } \\
\text { such as litigation } \\
\text { cost, fines for } \\
\text { environmental } \\
\text { accidents, fees for } \\
\text { waste discharge, } \\
\text { etc. }\end{array}$ & $\begin{array}{l}\text { Profits are sustainable } \\
\text { since people's } \\
\text { preferencer is } \\
\text { changing athical } \\
\text { consumerism) and } \\
\text { that's what makes the } \\
\text { market. Green firms } \\
\text { can also get } \\
\text { competitive advantage } \\
\text { thus allowing for } \\
\text { above normal profits. } \\
\text { Increased market } \\
\text { share due to } \\
\text { innovation in terms of } \\
\text { products and process } \\
\text { and shifting interest of } \\
\text { consumers. } \\
\text { Cost savings due to } \\
\text { reduced energy } \\
\text { consumption, a of } \\
\text { increased use onergy, } \\
\text { renewable ene } \\
\text { fuel efficient vehicles, } \\
\text { etc. }\end{array}$ \\
\hline
\end{tabular}




\section{CONCLUSION}

This case study shows the sustainability journey of the two beverages giants Coca-Cola and Pepsico and how they moved from anthropocentrism to sustaincentrism. There was a time when these companies were the prime target of boycotts and consumer rage over excessive water use, water pollution, waste disposal, etc. There used to be slogans like "Coca-Cola Quit India", people were trashing PepsiCo and Coca-Cola bottles, and there is today when these companies are the top two sellers in the Indian beverage market. This would not have been the case if these companies had continued with their anthropocentric approach. Profits were earned even under the traditional approach, but the companies had often faced backlash against their unsustainable methods. Today these companies have been earning huge profits with double-digit growth each year. They have managed to balance their financial and environmental goals. Although being in an industry so heavily dependent on water and other natural resources, criticisms keep coming their way. Yet the thing that has changed is the way the companies respond to the criticisms under the sustaincentric approach. Instead of shying away or green washing their public image, they actually take reasonable and immediate steps to shun such practices that are detrimental to the environmental health. For example, recently in 2017 , the public from the south Indian state of Tamil Nadu protested against PepsiCo and Coca-Cola in favour of their local product. Both these companies were criticised for overexploiting water from streams and rivers which caused irrigation problems for farmers in the area. In response to this, these companies scaled up the water recharge projects in India and expanded its total recharge potential to 5 billion litres which covered 7 states [22]. Today sustaincentrism has become important even for those companies that have anthropocentrism ingrained in their structure. This is because of the following: if a company wants to sustain in the long run, even with the sole intention to earn profits, they still depend on the environment for their raw materials, most important agricultural products, water, etc. which can only be supplied so long as the environmental conditions are suitable. So either way, sustaincentrism exists even when one wants to continue with anthropocentric values.

\section{REFERENCES}

[1] ICAEW, Survival of the fittest in business.

https://www.icaew.com/archive/technica

1/business-and-management/financialmanagement/financial-modelling-andforecasting/survival-of-the-fittest-inbusiness. Accessed: November 13, 2019.

[2] A. Pratap, Corporate Culture of Enron and How it Bred a Scandal. https://notesmatic.com/2016/11/corporat e-culture-enron-bred-scandal/. Accessed: October 10, 2019.

[3] P. Bansal, K. Roth, Why companies go green? A model of ecological responsiveness, Academy of Management Journal 43(2000) 4, 717736. https://doi.org/10.5465/1556363.

[4] Smartsheet, What Is Stakeholder Theory and How Does It Impact an Organization?

https://www.smartsheet.com/whatstakeholder-theory-and-how-does-itimpact-organization. Accessed: August 29, 2019.

[5] A.B. Casas, R.A. Burgess, The practical importance of philosophical inquiry for environmental professionals: A look at the intrinsic/instrumental value debate, Environmental Practice: Journal of the National Association of Environmental Professionals 14(2012) 3, 184-189.

[6] K.V. Kortenkamp, C.F. Moore, Ecocentrism and Anthropocentrism: moral reasoning about ecological commons dilemmas, Journal of Environmental Psychology 21(2001) 3, 261-272.

https://doi.org/10.1006/jevp.2001.0205.

[7] M. Decleris, The law of sustainable development, General principles. Environment Directorate-General, European commission, 2000, 53-56. 
https://www.pikpotsdam.de/avec/peyres q2003/talks/0917/sillence/background_li terature/sustlaw.pdf. Accessed: August 23, 2019.

[8] P. Wapner, R.A. Matthew, The Humanity of Global Environmental Ethics, The Journal of Environment Development 18(2009) 2, 203-222. https://doi.org/10.1177/10704965093346 93.

[9] B. MacKinnon, Ethics: Theory and Contemporary Issues, $5^{\text {th }}$ edition, Thomson Wadsworth, Belmont, California, 2007.

[10] T.N. Gladwin, J. Kennelly, T.S. Krause, Shifting paradigms for sustainable development: Implications for management theory and research, Academy of Management Review 20(1995), 874-907. http://www.jstor.org/stable/258959.

[11] M. Valente, Theorizing Firm Adoption of Sustaincentrism, Organization Studies 33(2012) 4, 563-591. https://doi.org/10.1177/01708406124434 $\underline{55}$.

[12] UK Essays, Coca-Cola and PepsiCo in India: A Question of Multinational Corporation, 2018. https://www.ukessays.com/essays/busine ss/coca-cola-and-pepsico-in-indiaquestion-of-multinational-corporationsbusiness essay.php?vref=1. Accessed: October 17, 2019.

[13] R. Ramesh, S. Jha, India bans soft drinks in pesticides row, 2006. https://www.theguardian.com/environme nt/2006/aug/07/food.business. Accessed: September 2, 2019.

[14] PTI, India: Coke, Pepsi attacked over ground water issue, 2004. Retrieved from

https://www.resilience.org/stories/200409-18/india-coke-pepsi-attacked-overground-water-issue/. Accessed: August 23, 2019.

[15] Earth Talk, Coca Cola charged with ground water depletion and pollution in India, 2019. https://www.thoughtco.com/coca-colagroundwater-depletion-in-india1204204. Accessed: December 29, 2019.
[16] A. Leonardo, Dumping Pepsi's Plastic, 1994.

https://multinationalmonitor.org/hyper/is sues/1994/09/mm0994_06.html.

Accessed: September 8, 2019.

[17] K. Hyams, Killa Cola, Ecologist: The Journal for Post Industrial Age, 2004. https://theecologist.org/2004/apr/01/killa -cola. Accessed: September 21, 2019.

[18] R. Bundhun, Coca Cola losing its fizz in India, 2017. https://www.thenational.ae/business/coc a-cola-losing-its-fizz-in-india-1.72443. Accessed: August 13, 2019.

[19] PepsiCo Reports Third Quarter, 2017. https://www.morningstar.com/news/prnewswire/PRNews_20171004NY06897/Pepsi Co-reports-third-quarter-2017results.html. Accessed: December 18, 2019.

[20] G. Colvin, Can Indra Nooyi keep investors sweet on Pepsi?, 2013. http://fortune.com/2013/06/13/can-indranooyi-keep-investors-sweet-on-pepsi/.

Accessed: August 12, 2019.

[21] Sustainable Brands, L'Oréal, PepsiCo Strike up New Partnerships to Push Forward Sustainability Agenda, 2017. http://www.sustainablebrands.com/news and_views/collaboration/sustainable_br ands/1\%E2\%80\%99or\%C3\%A9al_Pepsi Co_strike_new_partnerships_push_forw ard. Accessed: September 28, 2019.

[22] P. Neo, India sustainability is "integral": PepsiCo pours US\$5mn into local agriculture programme to make "global impact", 2018. https://www.foodnavigator asia.com/Article/2018/11/08/Indiasustainability-is-integral-PepsiCo-poursUS-5mn-into local-agricultureprogramme-to-make-global-impact. Accessed: August 19, 2019.

[23] S. Chadha, Why PepsiCo is building dams in India, 2010. https://www.greenbiz.com/blog/2010/04/ 27/why-pepsico-building-dams-india. Accessed: August 23, 2019.

[24] PepsiCo. Our History. http://www.PepsiCo.com/company/OurHistory. Accessed: October 13, 2019. 
[25] L. Mishra, All PET Recycled in State: PepsiCo India, 2019. https://www.thehindu.com/news/cities/m umbai/all-pet-recycled-in-state-pepsicoindia/article29434638.ece. Accessed: August 23, 2019.

[26] Packaging 360, PepsiCo announces new plastic waste management program in West $\quad 2019$. https://packaging360.in/news/pepsicoannounces-new-plastic-wastemanagement-programme-in-westbengal. Accessed: December 29, 2019.

[27] Coca-Cola Sustainability Report, 2018. https://www.ideasonpurpose.com/work/c oca-cola-2018-business-sustainabilityreport/. Accessed: August 24, 2019.

[28] HCCB, Plastic Waste Management, 2019. https://www.hccb.in/en/blog/CSRStories/Plastic-Waste-Management. Accessed: January 23, 2020.

[29] Global Sourcing Council, In conversation: An interview with Amit Shah, 2014.

https://www.gscouncil.org/inconversation-an-interview-with-amitsaha/. Accessed: September 12, 2019.

[30] Anandana. Coca-Cola India Foundation. https://www.anandana.org/. Accessed: August 13, 2019.

[31] Journey Staff. Packaging and Recycling, $2017 . \quad$ https://www.cocacolaindia.com/stories/sustainability/pack aging-recycling/3-lessons-coke-haslearned-since-launching-plantbottlepackaging. Accessed: November 7, 2019.

[32] M. Kuchinski, Corporate Responsibility Magazine Announces 2018100 Best Corporate Citizens, 2018. https://www.3blassociation.com/insights /corporate-responsibility-magazineannounces-2018-100-best-corporatecitizens. Accessed: October 3, 2019.

[33] The economic times. https://economictimes.indiatimes.com/ne ws/international/business/pepsico-indiawins-us-award-for-saving-more-than-17billion-litres-ofwater/articleshow/71483576.cms Accessed: December 23, 2019.
[34] A. Nicolaou, Coca-Cola Joins Push to Cut Plastic Waste. Financial Times, 2018.

https://www.ft.com/content/9059c2dcfd30-11e7-9b32-d7d59aace167. Accessed: September 18, 2019.

[35] The New Indian Express, Hindustan Coca Cola Takes Measures to Reduce Carbon Footprint, 2019. https://www.cocacolaindia.com/stories/sustainability/clim ate-protection/hindustan-coca-colatakes-measures-to-reduce-carbonfootprint. Accessed: October 19, 2019. 